\title{
Múltiplos anticorpos paraneoplásicos (Anti-Sox, Anti-HU e Antianfifisina) detectados em um paciente com encefalite límbica e câncer de pulmão.
}

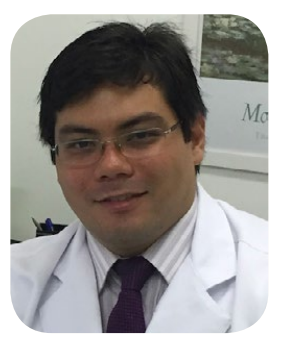

\section{RESUMO}

As encefalites imunomediadas são patologias que causam inflamação do encéfalo através da produção de autoanticorpos e podem ser encefalites autoimunes ou paraneoplásicas. Diversas síndromes clínicas são descritas em associação com anticorpos específicos, como a encefalite límbica, degeneração cerebelar subaguda, a síndrome Eaton-Lambert, síndrome do homem rígido e a neuropatia periférica. Alguns poucos relatos em literatura demostram associação de dois anticorpos com síndromes paraneoplásicas distintas. Este artigo descreve um paciente de 56 anos, que esteve internado no Hospital Santa Izabel, que apresentou como manifestação clínica uma encefalite límbica subaguda e uma inédita associação na literatura, que é a presença de três autoanticorpos detectados (Ant-Sox, Anti-HU e Antianfifisina) com um carcinoma de pulmão de pequenas células. Apesar do diagnóstico precoce, apresentou desfecho ruim decorrente da neoplasia de base e do padrão de autoanticorpos com alvos antigênicos intracelular. Ainda não se sabe se a presença de múltiplos anticorpos pode interferir para um prognóstico negativo.

\section{CORPO DO TEXTO}

As encefalites imunomediadas são patologias que causam inflamação do encéfalo através da produção de autoanticorpos e podem ser encefalites autoimunes ou paraneoplásicas. A encefalite autoimune é um grupo de doenças que podem estar ou não associadas a neoplasias, apresentam sintomas neuropsiquiátricos proeminentes e uma associação com anticorpos contra proteínas neuronais de superfície, canais iônicos ou receptores (ex.: Encefalite Anti-Receptor NMDA). As encefalites paraneoplásicas são sempre associadas a uma neoplasia e apresentam associação impor-

\author{
Thiago Gonçalves Fukuda ${ }^{1}$
}

tante com a produção de autoanticorpos predominantemente contra proteínas intracelulares alvo. ${ }^{1}$

Diversas síndromes clínicas são descritas em associação com anticorpos específicos como a encefalite límbica (Anti-Hu, Anti-LGl1, Anti-Caspr2), a degeneração cerebelar subaguda (Anti-Yo, Anti-Ri), a síndrome Eaton-Lambert (Anti-VGCC), síndrome do homem rígido (Antianfifisina) e a neuropatia periférica (Anti-HU, Anti-PC-2) ${ }^{2}$.

Este artigo descreve um paciente que esteve internado no Hospital Santa Izabel, que apresentou como manifestação clínica uma encefalite límbica subaguda e uma inédita associação com três autoanticorpos detectados.

O paciente em questão era um senhor de 56 anos, que deu entrada na emergência do hospital com um quadro de alterações cognitivas e comportamentais progressivas no período de 2 meses. O paciente apresentava um quadro de tabagismo importante e um etilismo social. Ao exame inicial foi percebido um quadro comportamental e desinibição importante associados a uma postura distônica em mãos (Figura 1). Durante o acompanhamento hospitalar, o paciente evoluiu com piora cognitiva e crises convulsivas. A investigação com ressonância magnética do crânio demonstrava uma alteração de sinal em região temporal medial compatível com um quadro de encefalite límbica. Foi então realizado um estudo do líquido cefalorraquiano $e$ o estudo de PCR para os vírus da família herpes, com o objetivo de excluir uma encefalite herpética.

Após excluir as encefalites infecciosas foi optado por investigação de uma encefalite imunomediada, com a realização da pesquisa anticorpos paraceoplásico e a pesquisa de neoplasia oculta. A tomografia de tórax demonstrou uma linfadenopatia com centro necrótico com parênquima pulmonar normal e a tomogra- 
fia por emissão de próton demonstrou um hipermetabolismo nos linfonodos hilares direitos. Foi optado por uma biópsia excisional dos linfonodos e confirmado na análise anatomopatológica um carcionoma de pequenas células pulmonar (Figura 2).

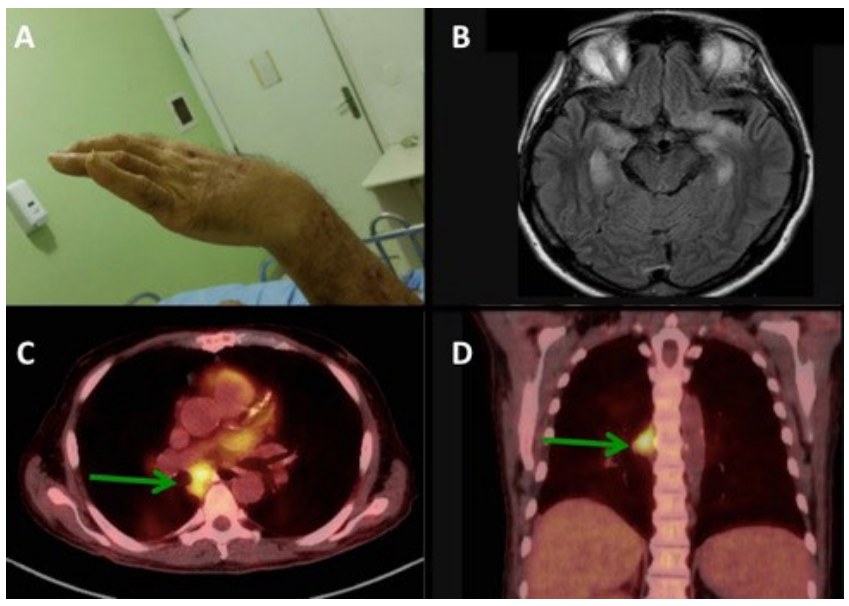

Figura 1 - Postura diatônica anormal (a). Hipersinal na sequência FLAIR envolvendo os lobos temporais mediais, o córtex da insula e os lobos frontais ínfero-lateral. (b) PET, demonstrando um aumento de captação nas cadeias de linfonodos hilares à direita $(c$ and $d)$.

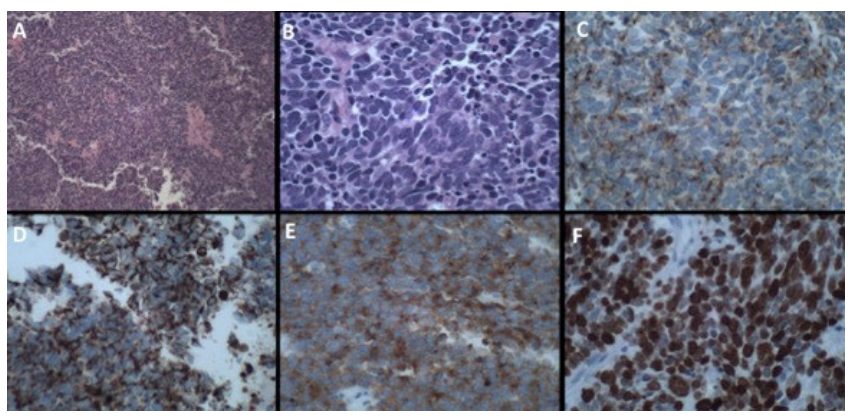

Figura 2 - Alterações anatomopatológicas em linfonodos: (a) HE com ampliação de 100x; neoplasia de pequenas células com citoplasma escasso e núcleos com cromatina granular. (b) HE ampliação de $400 \times$ neoplasia de pequenas células com citoplasma escasso e núcleos com cromatina granular e mitose evidente. (c-e) Imunofluorescência positiva para sinaptofisina, AE1AE3, (citoqueratina) e cromogranina, respectivamente, que favorecem o diagnóstico de carcinoma neuroendócrino de pequenas células. (f) Positividade para o KI-67, que indica um índice de proliferação celular superior a $20 \%$.
A análise de anticorpos paraneoplásicos foi positiva para Hu, Anfifisina e SOX1 e negativa para os anticorpos de superfície celular e sinápticos (Ma2, CV2/ CRMP5, GABAb, NMDAR, AMPAR, GAD).

Com o diagnóstico final de encefalite paraneoplásica associado a carcinoma pulmonar de pequenas células foi iniciado imunoterapia com metilprednisolona, plasmaférese, imunoglobulina e ciclofosfamida. O tratamento do carcinoma foi realizado com quimioterapia e radioterapia, no entanto o paciente faleceu por complicações infecciosas.

As síndromes paraneoplásicas clássicas ocorrem geralmente em associação a um único autoanticorpo. $\mathrm{Na}$ literatura médica havia alguns poucos relatos de casos de associação de síndromes paraneoplásicas clássicas (Lambert-Eaton associado a encefalite límbica) com dois autoanticorpos (Anti-VGCC e Anti-LGl1), mas esse é o primeiro artigo que demonstra a associação de uma única síndrome clássica com três autoanticorpos detectados. ${ }^{3,4,5,6}$

Uma outra lição demonstrada por esse caso é o fator prognóstico ruim da presença de anticorpos contra proteínas nucleares das células neuronais. Neste caso, a reação ocorre através de uma lesão diretamente, através do linfócito $\mathrm{T}$, que leva à destruição das células neuronais. Quando o alvo antigênico são antígenos de superfície neuronal, a resposta geralmente é mediada, predominantemente, por anticorpos que levam a um endocitose e inativação do alvo antigênico e nem sempre à destruição neuronal, conferindo em geral um melhor prognóstico ao paciente. Ainda não se sabe se a presença de múltiplos anticorpos pode interferir para um prognóstico negativo.

\section{REFERÊNCIAS}

1-Dalmau J, Graus Francesc. Antibody-Mediated Encephalitis. New England Journal of Medicine 2018; 378:840-851 DOI: 10.1056/NEJMra1708712.

2-Dalmau J, Geis C, Graus F. Autoantibodies to synaptic receptors and neuronal cell surface proteins in autoimmune diseases of the central nervous system. Physiol Rev 2017;97:839-87.

3- S. Kalraa, P. Gozzardb, S. Jacobc, A. Leonarda, P. Maddisonb. Limbic encephalitis and Lambert Eaton myasthenic syndrome - An immunological profile of a new syndrome. Clinical Neurology and Neurosurgery 116 (2014) 99-100.

4- Mason WP, Graus F, Lang B, Honnorat J, Delattre JY, Valldeoriola F, et. al. Small- cell lung cancer, paraneoplastic cerebellar degeneration and the Lambert-Eaton myasthenic syndrome. Brain 1997;120:1279-300. 
5- Titulaer MJ, Klooster R, Potman M, Sabater L, Graus F, Hegeman IM, et. al. SOX antibodies in small-cell lung cancer and Lambert-Eaton myasthenic syndrome: frequency and relation with survival. $\mathrm{J}$ ClinOncol 2009;27:4260-7.

6- Pittock SJ1, Lucchinetti CF, Parisi JE, Benarroch EE, Mokri B, Stephan CL, Kim KK, Kilimann MW, Lennon VA. Amphiphysin autoimmunity: paraneoplastic accompaniments. Ann Neurol. 2005 Jul;58(1):96-107.

1- Serviço de Neurologia do HSI

Endereço para correspondência:

thiagofukuda@gmail.com 